characters, such as Rain Man (1988), as well as the advent of the Internet and social media, which enabled the formation of support groups and allowed communication in ways that can be easier for people with ASD. As some of the stigma has ebbed, parents have become more willing to seek diagnoses for their children and even themselves.

One of the most powerful talks at the 2015 International Meeting for Autism Research was by John Elder Robison, who has been diagnosed with Asperger's syndrome. He told the room of scientists and clinicians,

"The reason diagnostic labels are so important to those of us with autism is that without those labels, we only have the labels we got

"As the stigma has ebbed, parents have become more willing to seek diagnoses."

in the streets, which are hateful." While we debate diagnostic criteria, we must remember that there are people receiving these labels (and not) who deserve respect, understanding and support.

Fittingly, NeuroTribes ends with the neurodiversity movement that is now emerging. Groups such as the Autism Self Advocacy Network campaign for spending less on finding 'cures' and more on designing appropriate support and accommodation for people with ASD and their families and caregivers.

Any work on ASD will be seen as a triumph by some and a travesty by others; Silberman has opted not to be shy. Great contributions include interviews with prominent scientists and self-advocates. He intersperses these with his own opinion, for example portraying the DSM-III as a way for psychiatrists to link to "Big Pharma”. His affection for detail can get in the way, as in a chapter on the development of radio and electronic bulletin boards. Readers should look elsewhere for a primer on what we do and do not understand of the basic biology of ASD; that is not Silberman's intent.

NeuroTribes is no casual read. The parent of a newly diagnosed child looking for information may be put off by the weight of past horrors on show. But for people in the field, or anyone seeking to understand the interplay between medical science and patient communities, it should be an essential resource. My own copy is already dog-eared and underlined throughout.

Chris Gunter is director of communications for the Marcus Autism Center at Children's Healthcare of Atlanta in Georgia. She is also at Emory University School of Medicine in Atlanta. e-mail:drchrisgunter@gmail.com

\title{
GENOMICS
}

\section{Bioethics on stage}

\author{
Brendan Maher reviews a play inspired by a famous \\ clash between geneticists and a Native American tribe.
}

$\lceil$ s n the early 1990s, researchers at Arizona State University (ASU) in Tempe collected blood samples from the Havasupai people, an isolated Native American tribe living in the Grand Canyon. A decade later, tribe members sued the university for misusing the samples, on the grounds that they had not been fully informed of the study's scope. The legal battle culminated in a US $\$ 700,000$ payout from ASU; the remaining samples were returned.

That much is true. But much else about the story is disputed. It has surfaced in articles and books as an example of the cultural sensitivities that come up in research. Some argue that it has become a fable of arrogant scientists riding roughshod over people's rights - a tale that has hardened mistrust between researchers and Native American groups.

The latest retelling is the drama Informed Consent, playing at the Duke on 42nd Street in New York City. Seasoned playwright Deborah Laufer sees her work as an exploration of truth and the clash between science and religion. Although the scientist at its centre comes across as a caricature of hubris, the piece effectively presents some ethical, legal and social complexities of modern genomics.

It is highly fictionalized. The real researchers were anthropologist John Martin and geneticist Therese Markow, who in the 1990 s were trying to find genetic underpinnings for the Havasupai's high incidence of type 2 diabetes - roughly 55\% among women and $38 \%$ among men. In the play, Ken (played by Jesse Perez) is a social anthropologist who has worked with an unnamed tribe in the Grand Canyon for 40 years, and

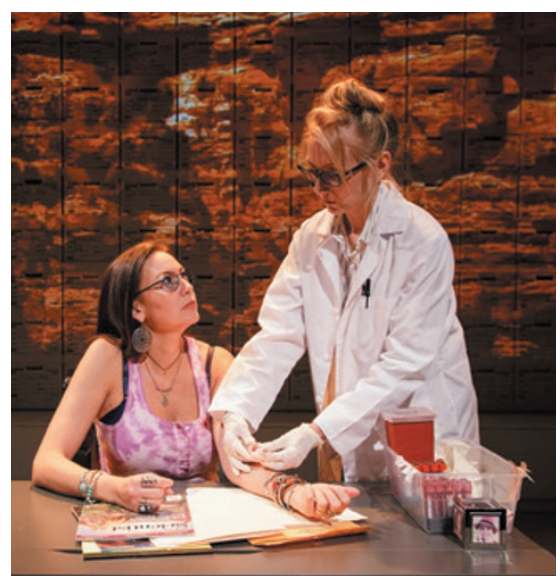

DeLanna Studi (left) and Tina Benko in

Informed Consent.
Informed Consent DEBORAH ZOE LAUFER The Duke on 42nd Street, New York City. Until 13 September.

Jillian (Tina Benko) is an ambitious genetic anthropologist struggling with the knowledge that she carries a genetic mutation that ensures that she will develop early-onset Alzheimer's disease.

Jillian jumps at Ken's offer to run a study looking for diabetes markers in tribe members' DNA. Soon, she reveals other intentions, such as studying how the tribe came to America - even though this would conflict with their own story about where they came from. Ken emphasizes that this is "strictly" a diabetes study. The fourth wall fading momentarily, Jillian tells the audience that he never said "strictly". Other cast members jump in to support her version, and Ken revises his line - a playful swipe at the indefinite nature of remembered truth.

Jillian convinces tribe members to hand over samples of their blood - which they deem sacred - by suggesting that DNA tests are their only hope of halting the diabetes epidemic. She also deludes herself into thinking that the work will lead to funding to pursue a cure for Alzheimer's. Her ambition is driven by fear, for herself and for her daughter Natalie (DeLanna Studi), who has a $50 \%$ chance of inheriting the mutant gene. In a parallel plot line, Jillian and her husband fight over whether to test Natalie.

The play crescendos as a tribal spokesperson (also played by Studi) confronts Jillian at a talk on the tribe's early migrations out of East Asia, saying that she had no right to use the samples to study this. Under threat of a lawsuit, Jillian's university fires her and the remaining samples are ceremonially returned.

In the mid-2000s, when the real case came to wide attention, progress on techniques for studying DNA was outpacing understanding of how the research might affect participants. There was no clear evidence that Markow or Martin had broken any rules, but the case and others prompted reconsideration of informed-consent documents, which are meant to lay out the risks for participants.

Laufer acknowledges the limits in presenting this story with certainty, especially in an engaging stage play, which Informed Consent most definitely is. She notes: "I guess what happened is much less important than what we can learn from the outcomes."

Brendan Maher is a features editor at Nature. 